\title{
Tổng hợp 2-methylketone nhờ cải biến biến dưỡng tế bào vi khuẩn
}

\section{Metabolic engineering of bacteria for the production of 2- methylketones}

\author{
Khuất Lê Uyên $\mathrm{Vy}^{1 *}$, Phạm Thị Mỹ Bình ${ }^{1}$, Nguyễn Thị Hồng Thương ${ }^{1}$, \\ Mai Huỳnh Hạnh Phúc ${ }^{2}$, Đinh Minh Hiệp ${ }^{3}$ \\ ${ }^{1}$ Trường Đại học Khoa học Tự nhiên, Đại học Quốc gia Thành phố Hồ Chí Minh, Việt Nam \\ ${ }^{2}$ Công ty Cổ phần dịch vụ Khoa học Công nghệ Chấn Nam, Việt Nam \\ ${ }^{3}$ Ban quản lý Khu Nông nghiệp Công nghệ cao Thành phố Hồ Chí Minh, Việt Nam \\ *Tác giả liên hệ, Email: kluvy@hcmus.edu.vn
}

THÔNG TIN

DOI: $10.46223 /$ HCMCOUJS. tech.vi.13.1.801.2018

Ngày nhận: 29/12/2017

Ngày nhận lại: 12/01/2018

Duyệt đăng: 15/01/2018

Tù khóa:

2-methylketone, kỹ thuật biến dưỡng, methylketone synthase

\section{TÓM TẮT}

2-Methylketone là chất tạo hương quan trọng trong ngành công nghiệp thực phẩm và mỹ phẩm. Ở thực vật, 2Methylketone chủ yếu có vai trò giúp cây trồng đối kháng với sâu hại. Gần đây, 2-Methylketone còn được xem là nguồn nguyên liệu tiềm năng cho sản xuất năng lượng sinh học. Việc khám phá ra hai gene methylketone synthase 1 (ShMKS1) và methylketone synthase 2 (ShMKS2) mã hóa cho hai enzyme chính tham gia trong sự sinh tổng hợp methylketone ở loài cà chua dại Solanum habrochaites và những gene tương đồng với chúng ở một số loài thực vật khác đã tạo nguồn gene cho nghiên cứu cải biến vi sinh vật nhằm tạo ra những chủng mới có khả năng sinh tổng hợp methylketone. Trong bài báo này, một số kết quả đạt được bước đầu trong nghiên cứu kỹ thuật biến dưỡng (metabolic engineering) hướng đến tối ưu hóa khả năng sản xuất methylketone nhờ vi khuẩn được cập nhật và phân tích. Trên cơ sở đó, chúng tôi bàn luận về những cơ hội và thách thức đi kèm, đồng thời thảo luận về một số đề xuất cải tiến cho các nghiên cứu tiếp theo.

\begin{abstract}
2-Methylketone is a class of compounds that are commonly used to flavor some foods and to improve the appeal of cosmetics. 2-Methylketones can act as a natural insecticide with low mammalian toxicity and little or no impact on the environment. Recently, methylketone has received more attention as a potential source of biodiesel. The discovery of two
\end{abstract}


Keywords:

2-methylketone, methylketone synthase, metabolic engineering

genes encoding two enzymes necessary for methylketone biosynthesis in the wild type tomato Solanum habrochaites, designated methylketone synthase 2 (ShMKS2) and methyl ketone synthase 1 (ShMKS1), and their homogeneous genes in some other plants have provided sources of the gene for metabolically engineering bacteria for the production of the 2methylketone. In this paper, we include new results achieved in this area in the past few years. The study sought to identify challenges and opportunities posed by the examples and to develop innovative suggestions for further research.

\section{2-Methylketone và tiềm năng ứng dụng}

2-Methylketone là nhóm hợp chất hữu cơ có nguồn gốc từ axit béo và chứa nhóm ketone ở nguyên tử carbon thứ hai. 2-Methylketone được phát hiện vào năm 1858 trong tinh dầu cây cửu lý hương Ruta graveolens (Williams, 1858) và sau đó được tìm thấy trong vi sinh vật, thực vật, côn trùng và tế bào động vật hữu nhũ (Forney \& Markovetz, 1971). Methylketone tồn tại trong tự nhiên đa dạng về chiều dài chuỗi: methylketone chuỗi ngắn có khung carbon dài 3-9 nguyên tử carbon, methylketone chuỗi trung bình gồm 11-13 nguyên tử carbon, methylketone chuỗi dài 15-17 nguyên tử carbon. Tùy thuộc vào chiều dài chuỗi, các hợp chất methylketone có những vai trò khác nhau trong sinh giới và được ứng dụng trong các lĩnh vực khác nhau. Methylketone được tìm thấy trong thực vật thường có từ 7-15 nguyên tử cacbon: 2-heptanone (7C), 2-nonanone (9C), 2-undecanone (11C), 2-tridecanone (13C) và 2-pentadecanone (15C). Một vài nghiên cứu chứng minh các 2-methylketone, đặc biệt là 2-tridecanone, được tìm thấy trong thực vật là nhóm hợp chất có tính kháng sâu tự nhiên, hỗ trợ cây trồng chống lại sâu bệnh gây hại (Dimock \& Kennedy, 1983). Một số nghiên cứu về tác động gây độc của methylketone trên người và gia súc cho thấy mặc dù methylketone gây chết các loại côn trùng gây hại nhưng không có tác động gây độc nào trên người và gia súc (Antonious, 2004). Ngoài thực vật, methylketone còn được phát hiện trong một số loài côn trùng. 2-Pentadecanone được xác định là một trong các thành phần của chất dẫn dụ giới tính (pheromone) được tổng hợp khá nhiều trong ruồi giấm Drosophila busckii (Schaner, Tanico-Hogan, \& Jackson, 1989). 2-Tridecanone, 2-pentadecanone và 2-heptadecanone được phát hiện trong thành phần hợp chất bay hơi tiết ra từ tuyến hậu môn của loài ong Frieseomelitta varia (Patricio, López, Maile, \& Morgan, 2003). 2-Heptanone còn được tìm thấy trong tuyến hàm dưới của kiến Atta texana và Conomyrma pyramica có tác dụng thu hút hoặc xua đuổi các loài khác tùy thuộc vào hợp chất này được tiết ra với hàm lượng thấp hay cao (Blum \& Warter, 1966; Moser, Brownlee, \& Silverstein, 1968). Trong những năm 1950 -1970, các nhà khoa học đã phát hiện ra methylketone hiện diện trong môi trường nuôi cấy của nhiều loài vi khuẩn và nấm. Điển hình như Mycobacterium rhodochrous tổng hợp được 2-undecanone từ $n$-undecane (Lukins \& Foster, 1963) hay Pseudomonas methanica và Mycobacterium smegmatis có thể tổng hợp các methylketone chuỗi ngắn như 2-butanone, 2-pentanone và 2-hexanone từ nguồn alkane tương ứng của chúng (Leadbetter \& Foster, 1959; Lukins \& Foster, 1963). Nấm Penicillium caseicolum được phân lập từ phô mai Camembert có khả năng tạo ra lượng lớn methylketone có mạch carbon dài từ 
C3-C13 từ cơ chất là sữa bột (Karahadian, Josephson, \& Lindsay, 1985). Từ lâu, methylketone đã được sử dụng làm chất tạo hương cho các sản phẩm từ sữa (Forney \& Markovetz, 1971). Một số methylketone chuỗi ngắn là thành phần tạo hương vị đặc trưng cho phô mai xanh như 2-propanone, 2-pentanone, 2-heptanone và 2-nonanone (Alonso, Fontecha, \& Juárez, 1999). Tại Mỹ, một hỗn hợp tạo hương vị đặc biệt của kem được nhiều người ưa thích bao gồm axit 9-decenoic và hỗn hợp của 2-undecanone, 2-tridecanone và 2-pentadecanone (Sevenants, 1983). 2-Nonanone, 2-undecanone, 2-tridecanone, và 2-pentadecanone đã được cho phép sử dụng làm hương liệu cho thực phẩm, nước hoa và tinh dầu bởi Cục Quản lý Thực phẩm và Dược phẩm Mỹ (như GRAS) (Hall \& Oser, 1965). Đáng chú ý hơn, gần đây methylketone nhận được nhiều sự quan tâm của các nhà nghiên cứu năng lượng sinh học vì đây là nhóm hợp chất có trị số kích nổ cetane cao. Hỗn hợp của 2-undecanone và 2-tridecanone với tỉ lệ 50/50 về khối lượng có trị số kích nổ cetane là 58,4 (Goh, Baidoo, Keasling, \& Beller, 2012). Methylketone có tính ưa nước và nhiệt độ nóng chảy thấp hơn các axit béo hiện đang được sử dụng nhiều trong sản xuất dầu diesel sinh học, vì thế nhóm hợp chất này hứa hẹn sẽ là một lựa chọn mới trong việc sản xuất nguồn nhiên liệu sinh học có thể tái sinh, an toàn và thân thiện với môi trường, có thể thay thế cho nguồn nhiên liệu dầu mỏ và khí đốt đang ngày càng cạn kiệt.

\section{Sinh tổng hợp methylketone là con đường chuyển hóa chuyên biệt của một số loài thực vật?}

Mặc dù những ứng dụng của 2-methylketone đã được biết đến từ khá lâu, những nghiên cứu về cơ sở phân tử của quá trình sinh tổng hợp các hợp chất methylketone ở thực vật mới được công bố trong những năm gần đây trên loài cà chua dại Solanum habrochaites. Các nhà nghiên cứu đã nhận thấy rằng hai gene $S h M K S 1$ và $S h M K S 2$ biểu hiện mạnh trong các tế bào lông tiết ở thân và lá của những cây cà chua dại tích lũy nhiều methylketone trong khi lại ít biểu hiện trong những cây cà chua đã được thuần hóa $S$. lycopersicum chỉ tích lũy một lượng không đáng kể các methylketone. Trên cơ sở đó, hai gene này đã được phân lập và nghiên cứu chức năng (Ben-Israel et al., 2009; Fridman et al., 2005; Yu et al., 2010). Gene thứ nhất, ShMKS2, mã hóa cho một protein thuộc nhóm thioesterase II với đặc trưng là chứa vùng gấp cuộn "hotdog”. ShMKS2 có hoạt tính của một 3-ketoacyl-ACP thioesterase, xúc tác phản ứng thủy phân liên kết thioester trong cơ chất 3-ketoacyl-ACP, chất trung gian trong con đường sinh tổng hợp axit béo diễn ra ở lục lạp thể của thực vật, để tạo thành các 3-ketoaxit tương ứng. Gene thứ hai, ShMKS1, mã hóa cho một protein thuộc nhóm thioesterase I với đặc trưng là chứa vùng gấp cuộn kiểu " $\alpha / \beta$ hydrolase". Tuy nhiên, ở loài cà chua dại, ShMKS1 không có hoạt tính hydrolase như đa số các thành viên khác trong nhóm enzyme này mà lại thể hiện hoạt tính 3-ketoaxit decarboxylase (Auldridge et al., 2012), xúc tác phản ứng khử nhóm carbonyl của các 3-ketoaxit để tạo thành sản phẩm chuyển hóa cuối cùng là 2-methylketone có chiều dài chuỗi ngắn hơn một nguyên tử carbon. Hai bước phản ứng cuối cùng trong con đường sinh tổng hợp methylketone diễn ra ở loài cà chua dại có thể được mô tả như ở Hình 1. 


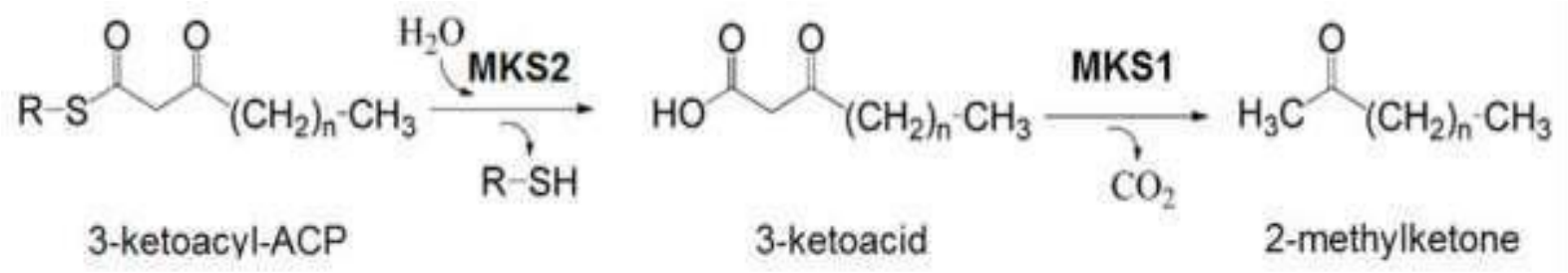

Hình 1. Chuỗi phản ứng tổng hợp methylketone (Yu et al., 2010)

Một lượng nhỏ methylketone đôi khi cũng được tìm thấy trong các loài thực vật khác ngoài chi Solanum (Henricsson, Westerholm, Nilsson, \& Berggren, 1996; Jasperson \& Jones, 1947) nhưng cơ chế sinh tổng hợp methylketone ở những loài này vẫn chưa được xác định. Sự hiện diện của các protein tương đồng với MKS1 và MKS2 ở các loài khác không thuộc chi Solanum đã đặt ra câu hỏi rằng hai protein này có tham gia trong quá trình tổng hợp methylketone, dù chỉ với một lượng rất nhỏ, ở những loài thực vật này không? Và bằng cách nào hai protein ShMKS1 và ShMKS2 đã có được khả năng xúc tác sinh tổng hợp một lượng đáng kể methylketone ở loài cà chua dại?

Câu trả lời khả dĩ là: bất kể chức năng (hoạt tính) đầu tiên của MKS2 là gì, sự gia tăng biểu hiện của gene này sẽ dẫn đến làm tăng hoạt tính enzyme thay thế, vốn chỉ ở mức thấp, của protein được mã hóa gene này. Kết quả này kết hợp với sự gia tăng đồng thời dòng chuyển hóa tổng hợp axit béo có thể đã làm tăng lượng methylketone được tổng hợp so với ban đầu (do 3ketoaxit có thể được decarboxyl hóa một phần ở điều kiện thường thành methylketone). Do methylketone có hoạt tính kháng côn trùng và sâu hại, những cây có khả năng tổng hợp methylketone có ưu thế hơn so với những cây khác và kết quả là đặc tính này được giữ lại qua quá trình chọn lọc tự nhiên lâu dài. Tuy nhiên, nếu chỉ một phần nhỏ 3-ketoaxit được chuyển hóa thành methylketone thì sự biểu hiện vượt mức protein ShMKS2 mà không đi kèm với sự hiện diện của enzyme decarboxylase có thể dẫn đến tích lũy một lượng lớn chất trung gian 3ketoaxit, gây trở ngại cho quá trình sinh tổng hợp axit béo. Vì lẽ đó, enzyme MKS1 nguyên bản với hoạt tính khử nhóm carbonyl của các 3-ketoaxit ở mức độ thấp đã được chọn lọc tự nhiên giữ lại để mang lại lợi ích cho cây bằng cách khử nhóm carbonyl của các 3-ketoaxit và gia tăng tổng hợp methylketone kháng sâu hại. Điều thú vị là ShMKS2 ở cà chua dại và các protein tương đồng với ShMKS2 ở một số loài thực vật khác đều xúc tác cho phản ứng thủy phân tương tự nhau, đề nghị rằng hoạt tính thioesterase của các $\mathrm{MKS} 2$ này vốn đã xuất hiện từ khá lâu trong lịch sử tiến hóa. Ngược lại, protein ShMKS1 và SIMKS1a về cơ bản lại khác với các protein tương đồng với chúng được tìm thấy ở những loài khác. Sự thay thế Ser trong bộ ba xúc tác cần thiết cho hoạt động $\alpha / \beta$-hydrolase của nhiều protein trong họ $\alpha / \beta$-hydrolase bằng Ala (ở vị trí 87 trong ShMKS1) khiến cho ShMKS1 và SIMKS1a không có hoạt tính hydrolase như các protein tương đồng của nó (Hotelier et al., 2004). Như vậy, hoạt tính 3-ketoaxit decarboxylase của ShMKS1 dường như chỉ mới xuất hiện gần đây, có thể là chỉ trong chi Solanum. Sự tiến hóa chức năng của MKS1 và những thay đổi về mức độ biểu hiện của ShMKS2 và ShMKS1 ở cà chua dại đã khiến cho loài thực vật này có khả năng tổng hợp và tích lũy được nhiều methylketone trong lông tiết của lá và thân. Ngoài cà chua dại Solanum habrochaites có khả năng tổng hợp nhiều methylketone chuỗi trung bình, những nghiên cứu sơ khởi gần đây của nhóm chúng tôi đã xác định được thêm một loài thực vật đặc hữu ở Việt Nam có khả năng tổng hợp nhiều methylketone chuỗi dài là lan Giả hạc Dendrobium superbum (dữ liệu chưa công 
bố). Những nghiên cứu về cơ sở di truyền và sinh hóa của quá trình sinh tổng hợp methylketone ở loài này sẽ góp phần làm sáng tỏ thêm những hiểu biết của chúng ta về sự đa dạng trong nguồn gene MKS2 ở thực vật. Kết quả từ những công bố khoa học đã nêu phần nào đã cho thấy rằng sinh tổng hợp methylketone là con đường chuyển hóa chuyên biệt ở một số loài thực vật với chức năng được tìm thấy là kháng côn trùng và sâu hại.

\section{Hoạt tính enzyme của các protein được mã hóa bởi MKS2 và MKS1}

Khi biểu hiện trong cà chua dại và cả khi được biểu hiện tái tổ hợp trong vi khuẩn $E$. coli, ShMKS2 thủy phân hiệu quả nhất cơ chất 3-ketomyristoyl-ACP và 3-ketolauroyl-ACP và tạo thành 3-ketoaxit tương ứng là axit 3-ketomyristic (14C) và axit 3-ketolauric (12C), còn ShMKS1 có hoạt tính decarboxylase sẽ khử nhóm carboxyl của 3-ketoaxit tạo thành 2methylketone (Yu et al., 2010).

Cấu trúc tinh thể của protein enzyme ShMKS1 đã được xác định (Auldridge et al., 2012). Kết quả phân tích cho thấy ShMKS1 là một thành viên khác biệt thuộc họ $\alpha / \beta$-hydrolase (thioesterase nhóm I), trong đó bộ ba axit amin có vai trò xúc tác của đa số enzyme họ $\alpha / \beta$ hydrolase là Ser-His-Asp đã được thay thế bằng bộ ba Ala-His-Asn. Kết quả là ShMKS1 có hoạt tính decarboxylase thay vì hoạt tính hydrolase như đa số các thành viên khác trong họ enzyme này. Thông tin về cấu trúc tinh thể của ShMKS1 chính là cơ sở để tiến hành nghiên cứu vai trò của một số axit amin tại trung tâm hoạt động của enzyme ShMKS1 đối với tính đặc hiệu cơ chất của enzyme này. Cụ thể, sự thay đổi amino axit Cysteine thứ 125 thành Tryptophan (W) hoặc Glycine thứ $129(\mathrm{G})$ thành Tryptophan (W) giúp tăng hoạt tính xúc tác của enzyme ShMKS1 lên tương ứng 32 hoặc 44 lần trên cơ chất chuỗi ngắn 3-ketoheptanoate (C8) (Auldridge et al., 2012).

Cho đến nay cấu trúc tinh thể của ShMKS2 và các protein tương đồng với ShMKS2 từ các loài thực vật khác vẫn chưa được xác định. Tuy nhiên, các nhà khoa học đã có các bằng chứng thực nghiệm cho thấy ShMKS2 là một thioesterase có cấu trúc gấp cuộn kiểu "hotdog"tương tự với enzyme 4- hydroxybenzoyl-CoA thioesterase (4HBT) được tìm thấy ở vi khuẩn Pseudomonas sp (Benning et al., 1998) mặc dù hai protein này chỉ tương đồng < $15 \%$ về trình tự. ShMKS2 thể hiện hoạt tính thioesterase, xúc tác thủy phân liên kết thioester của cơ chất 3ketoacyl-ACP tạo thành 3-ketoaxit trong phản ứng kế cuối của con đường sinh tổng hợp methylketone ở cà chua dại $S$. habrochaites (Yu et al., 2010) còn enzyme 4HBT xúc tác thủy phân liên kết thioester giữa $\mathrm{CoA}$ và nhóm 4-hydroxybenzoyl trong quá trình chuyển hóa 4chlorobenzoate thành 4-hydroxybenzoate ở vi khuẩn Pseudomonas sp (Benning et al., 1998). Kết quả sắp gióng cột các trình tự protein $\mathrm{MKS} 2$ ở thực vật với trình tự của 4HBT từ vi khuẩn Pseudomonas sp. cho thấy vị trí của axit amin aspartate có vai trò quyết định hoạt tính thioesterase của các protein enzyme chứa cấu trúc gấp cuộn kiểu "hotdog" như 4HBT đã được bảo tồn ở tất cả các protein MKS2 được sắp gióng cột (Ben-Israel et al., 2009). Đồng thời, đột biến điểm định hướng nhằm thay đổi aspartate tại vị trí này thành alanine đã dẫn đến sự bất hoạt các MKS2 đã khảo sát (Yu et al., 2010). Tuy nhiên, những yếu tố nào đã quyết định tính đặc hiệu cơ chất của các enzyme MKS2 vẫn là một câu hỏi còn đang bỏ ngõ.

Năm 2014, Pulsifer và cộng sự đã phân lập được bốn gene thuộc họ acyl thioesterase từ Arabidopsis thaliana mã hóa cho các protein tương đồng 72-80\% với ShMKS2 và đặt tên lần 
lượt là acyl-lipid thioesterase 1 (ALT1), $A L T 2, A L T 3$ và $A L T 4$. Khi biểu hiện các gene này trong tế bào $E$. coli $\mathrm{K} 27$, là chủng khuyết gene $F a d D$ - gene mã hóa enzyme acyl-CoA synthetase, các enzyme ALT sử dụng cơ chất acyl-ACP để tạo thành các axit béo đa dạng về chiều dài chuỗi carbon (C8-C16), mức độ bão hòa và trạng thái oxy hóa của chuỗi. Đặc biệt, enzyme ALT2 có khả năng sử dụng cơ chất 3-ketoacyl-ACP để tổng hợp 3-ketoaxit chuỗi ngắn $(8 \mathrm{C}$, 10C) khi được biểu hiện tái tổ hợp trong tế bào $E$. coli K27 (Pulsifer et al., 2014). Những kết quả này cho thấy có sự khác biệt về số lượng gene $M K S 2$ ở các loài thực vật khác nhau, đồng thời cũng phản ánh sự đa dạng về hoạt tính enzyme của các protein được mã hóa bởi những gene này.

\section{thức}

\section{Tổng họ̣p methylketone bằng cải biến biến dưỡng vi sinh vật - Cơ hội và thách}

Các hợp chất methylketone có nhiều vai trò quan trọng trong đời sống tự nhiên và trong ứng dụng sản xuất. Tuy nhiên, việc tổng hợp và sản xuất methylketone ở quy mô công nghiệp hiện nay chủ yếu bằng phương pháp hóa học thông qua quá trình oxi hóa các hydrocarbon. Do đó việc sản xuất methylketone bằng con đường chuyển hóa sinh học, an toàn và thân thiện với môi trường thông qua kỹ thuật biến dưỡng là một hướng đi mới đang được các nhà khoa học quan tâm.

Những hiểu biết về cơ sở phân tử và sinh hóa của sự sinh tổng hợp methylketone ở thực vật đã tạo tiền đề cho những nghiên cứu sử dụng kỹ thuật biến dưỡng vi sinh vật để tổng hợp methylketone ở quy mô công nghiệp. Vào năm 2012, Park và cộng sự đã thiết kế con đường sinh tổng hợp methylketone từ glucose trong tế bào $E$. coli bằng cách biểu hiện vượt mức hai gene $S h M K S 1$ và $S h M K S 2$ đã được tối ưu hóa mã di truyền để phù hợp với hệ thống biểu hiện của $E$. coli. Tế bào $E$. coli bình thường tổng hợp một lượng không đáng kể các methylketone nhưng có khả năng tổng hợp 3-ketoacyl-ACP hoặc 3-ketoacyl-CoA - tiền chất trực tiếp để tạo ra methylketone. ShMKS2 xúc tác sự thủy phân liên kết thioester của 3-ketoacyl-ACP hoặc CoA tạo thành 3-ketoaxit. ShMKS1 xúc tác sự decarboxyl hóa các 3-ketoaxit tạo thành methylketone. Để chuyển hướng dòng carbon sang nhánh tổng hợp methylketone, nhóm tác giả đã tiến hành loại đi những gene tham gia trong những con đường lên men tổng hợp ethanol $(a d h E)$, lactate $(l d h A)$ và acetate $(p t a, p o x B)$ ở tế bào vi khuẩn $E$. coli, kết quả là lượng methylketone được tổng hợp tăng lên gấp đôi. Thông qua việc tối ưu hóa các điều kiện nuôi cấy và sử dụng kỹ thuật biến dưỡng hợp lý, cụ thể là bổ sung thêm glucose vào môi trường nuôi cấy với nồng độ $50 \mathrm{~g} / \mathrm{L}$, nuôi cấy lắc ở $37^{\circ} \mathrm{C}$ trong 48 giờ ơ điều kiện oxy hòa tan (DO) là $10 \%$, nhóm nghiên cứu đã có thể đạt được nồng độ methylketone cao gấp 75 lần so với mức ban đầu, trong đó chủng $E$. coli MG1655 $\Delta a d h E \Delta l d h A \Delta p o x B \Delta p t a$ pTrcHis2A-shmks2-shmks1 được ghi nhận có khả năng tổng hợp methylketone ở mức cao nhất (gần bằng $500 \mathrm{mg} / \mathrm{L}$ ) trong số các chủng vi sinh được cải biến di truyền. Hai methylketone được tạo ra từ chủng vi khuẩn $\mathrm{E}$. coli siêu biểu hiện hai gene ShMKS2 và ShMKS1 trong nghiên cứu này là 2-tridecanone (C13) và 2-undecanone (C11) (Park et al., 2012). 


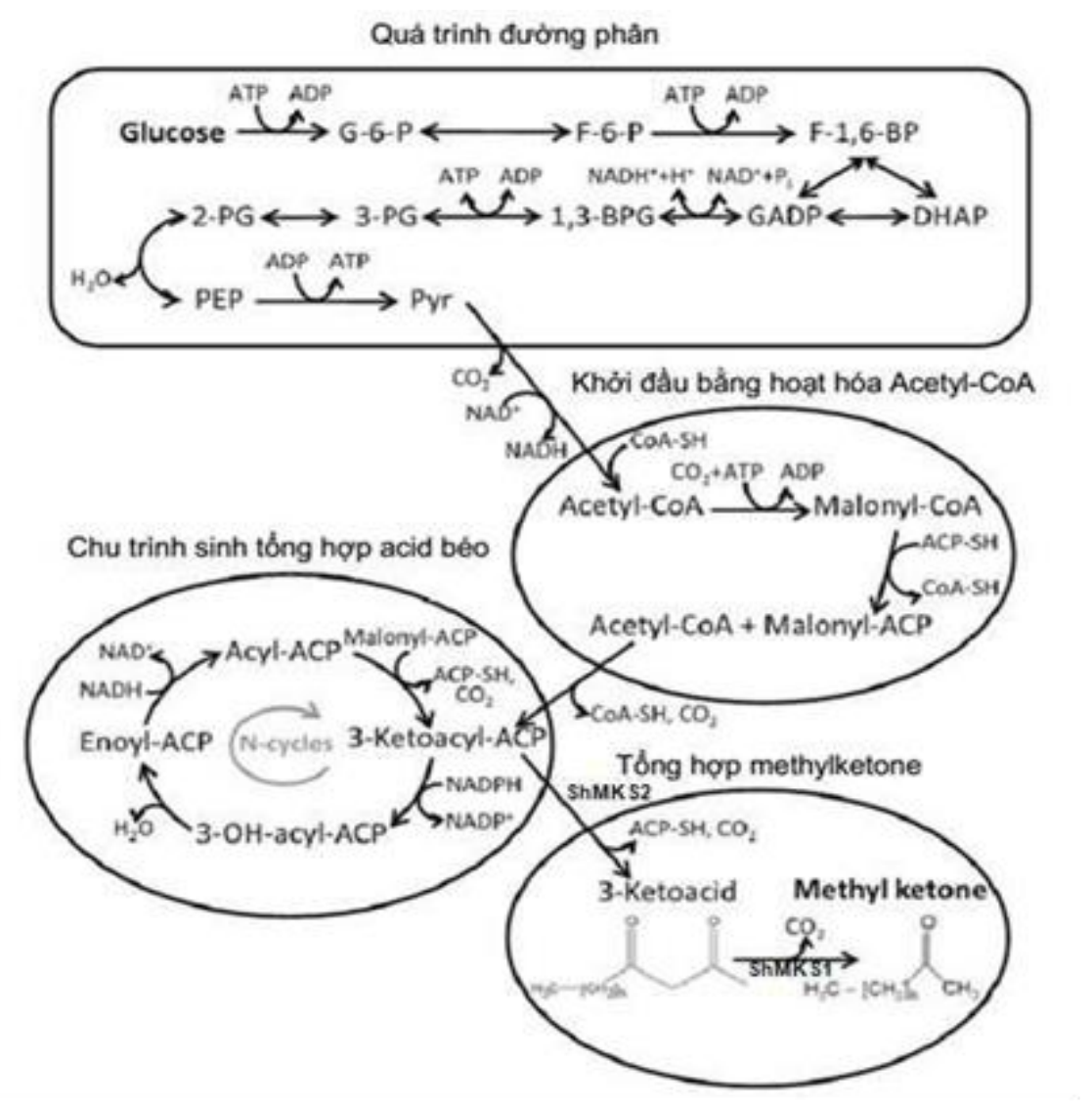

Hình 2. Con đường sinh tổng hợp methylketone trong tế bào E. coli siêu biểu hiện hai gene ShMKS1 và ShMKS2 từ cơ chất ban đầu là glucose (Park et al., 2012)

Ghi chú: G-6-P: glucose-6-phosphate; F-6-P: fructose-6-phosphate; F-1,6-BP: fructose-1,6- bisphosphate; DHAP: dihydroxyacetone-phosphate; GADP: glyceraldehyde-3-phosphate; 1,3-BPG: 1,3-bisphospho-glycerate; 3-PG: 3phospho-glycerate; 2-PG: 2-phospho-glycerate; PEP: phosphoenol pyruvate; Pyr: pyruvate

Cũng trong năm 2012, Goh và cộng sự đã tạo được chủng vi khuẩn $E$. coli biểu hiện vượt mức đồng thời $F a d B$ - gene mã hóa enzyme tổng hợp 3-ketoacyl-CoA và $F a d M$ - gene mã hóa cho enzyme thioesterase phân giải 3-ketoacyl-CoA thành 3-ketoaxit. Nhờ sự cải biến di truyền này, chủng mới có khả năng tổng hợp methylketone đạt mức $380 \mathrm{mg} / \mathrm{L}$, bao gồm chủ yếu là 2-undecanone và 2-tridecanone (Goh et al., 2012).

2-Undecanone và 2- tridecanone là các methylketone có chiều dài chuỗi trung bình có chỉ số kích nổ cetane cao, tuy nhiên, nhiệt độ nóng chảy của chúng cũng tương đối cao là một điều bất lợi cho đặc tính của nhiên liệu nhiệt lạnh. Trong khi đó, các methylketone chuỗi ngắn và các methylketone với khung carbon chưa bão hòa lần lượt có nhiệt độ nóng chảy thấp hơn các methylketone chuỗi dài và các methylketone có chứa liên kết đôi trong phân tử (Goh et al., 2012).

Sự phát hiện ra gene mã hóa enzyme acyl-lipid thioesterase 2 (ALT2) ở Arabidopsis thaliana có hoạt tính thủy phân 3-ketoacyl-ACP chuỗi ngắn $(8 \mathrm{C}, 10 \mathrm{C})$ (Pulsifer et al., 2014) là tiền đề để chúng tôi cải biến con đường biến dưỡng trong $E$. coli hướng đến tổng hợp các methylketone chuỗi ngắn. Năm 2015, Khuat, Do, và Nguyen đã biểu hiện vượt mức gene $A L T 2$ 
trong $E$. coli $\mathrm{C} 41$ (DE3). Chủng $E$. coli tái tổ hợp này có khả năng sử dụng cơ chất sẵn có trong tế bào để tổng hợp và tiết ra môi trường nuôi cấy các 3-ketoaxit và sự decarboxyl hóa các 3ketoaxit này ở nhiệt độ cao dẫn đến sự tạo thành các sản phẩm cuối methylketone chuỗi ngắn tương ứng. Trong nghiên cứu này và các nghiên cứu khác đã công bố, chủng $E$. coli chỉ biểu hiện hoặc ALT2 hoặc ShMKS2 và vì vậy dịch nuôi cấy thu được sau khi lên men cần được đun nóng ở nhiệt độ $75^{\circ} \mathrm{C}$ mới chuyển hóa toàn bộ 3-ketoaxit sinh ra thành 2-methylketone (Khuat et al., 2015). Nói cách khác, sản phẩm cuối methylketone chuỗi ngắn không được tổng hợp trực tiếp bởi $E$. coli mà đã được tổng hợp gián tiếp thông qua việc decarboxyl hóa các 3-ketoaxit do E. coli sinh ra trong môi trường nuôi cấy ở $75^{\circ} \mathrm{C}$. Để thay thế bước xử lý nhiệt, hướng đến việc sản xuất methylketone chuỗi ngắn hoàn toàn bằng con đường biến dưỡng sinh học, việc đồng biểu hiện ALT2 với một protein có hoạt tính 3-ketoaxit decarboxylase có giúp chuyển hóa trực tiếp 3-ketoaxit thành methylketone? Thêm vào đó, enzyme ShMKS1G129W, dạng đột biến thay thế axit amin $\mathrm{G}$ (Glycine) tại vị trí 129 bằng axit amin W(Tryptophan) trên ShMKS1, hoạt động hiệu quả gấp 44 lần so với ShMKS1 trên cùng cơ chất 3-ketoaxit chuỗi ngắn (Auldridge et al., 2012), vì vậy có thể nghiên cứu đồng biểu hiện enzyme ShMKS1G129W với ALT2 để thử nghiệm tổng hợp methylketone chuỗi ngắn hoàn toàn bằng con đường chuyển hóa sinh học.

Ngoài ra, để cải thiện hiệu suất dịch mã, dẫn đến việc tăng sản lượng methylketone tạo thành, các protein ALT2 và ShMKS1G129W cần phải được tối ưu mã di truyền cho phù hợp với hệ thống biểu hiện $E$. coli. Thêm vào đó, các hệ thống biểu hiện khác có thể được xem xét thử nghiệm để chọn lọc hệ thống tế bào chủ phù hợp cho việc sản xuất methylketone đạt hàm lượng cao.

Trong tất cả các nghiên cứu về kỹ thuật biến dưỡng để sản xuất methylketone, sản phẩm methylketone sinh ra là một hỗn hợp các methylketone khác nhau về chiều dài chuỗi và mức độ oxy hóa của khung carbon. Việc này gây khó khăn cho việc tách riêng rẻ từng hợp chất methylketone để phục vụ cho các ứng dụng khác nhau. Một câu hỏi khác được đặt ra là làm sao tổng hợp được methylketone có chiều dài hoặc mức độ oxy hóa của khung carbon như mong muốn thông qua sự cải biến có định hướng trình tự axit amin của các enzyme MKS2 này. Việc tìm kiếm và phân lập thêm các gene $M K S 2$ ở các loài thực vật khác nhau đã và đang góp phần làm phong phú thêm bộ sưu tập các enzyme MKS2, trong đó mỗi enzyme sẽ có tính đặc hiệu cơ chất khác nhau. Nguồn enzyme MKS2 đa dạng này là cơ sở để phân tích và xác định các axit amin có vai trò quyết định tính đặc hiệu của enzyme với cơ chất 3-ketoacyl-ACP. Cụ thể, tiến hành so sánh trình tự axit amin của các protein MKS2 tương đồng này với nhau, đồng thời tiến hành so sánh sản phẩm methylketone tạo thành có thể cung cấp thông tin về mối liên quan giữa các thay đổi trong trình tự axit amin của protein $\mathrm{MKS} 2$ với các chiều dài chuỗi carbon của sản phẩm methylketone tạo thành. Trong tương lai, nếu việc phân tích cấu trúc của enzyme MKS2 thành công, chúng tôi hy vọng là có thể tạo ra những đột biến điểm định hướng nhằm thay đổi cấu trúc của enzyme MKS2 theo hướng hoạt động hiệu quả với các cơ chất 3-ketoacyl$\mathrm{ACP}$ chuỗi ngắn hơn hoặc dài hơn một cách chủ động, đáp ứng các nhu cầu ứng dụng khác nhau của nhóm hợp chất này. 


\section{LÒ̀I CẢM ƠN}

Nghiên cứu này được tài trợ bởi chương trình Vườn ươm Sáng tạo Khoa học và Công nghệ trẻ được chủ trì bởi Trung tâm Phát triển Khoa học và Công nghệ Trẻ.

\section{Tài liệu tham khảo}

Alonso, L., Fontecha, J., \& Juárez, M. (1999). Development of a headspace gas chromatographic-mass spectrometric method for determining methyl-ketones and secondary alcohols in blue cheese. Journal of Chromatographic Science, 37(4), 108-112.

Antonious, G. (2004). Persistence of 2-tridecanone on the leaves of seven vegetables. Bulletin of Environmental Contamination and Toxicology, 73(6), 1086-1093.

Auldridge, M. E., Guo, Y., Austin, M. B., Ramsey, J., Fridman, E., Pichersky, E., \& Noel, J. P. (2012). Emergent decarboxylase activity and attenuation of $\alpha / \beta$-hydrolase activity during the evolution of methylketone biosynthesis in tomato. The Plant Cell, 24(4), 1596-1607.

Ben-Israel, I., Yu, G., Austin, M. B., Bhuiyan, N., Auldridge, M., Nguyen, T., ... Fridman, E. (2009). Multiple biochemical and morphological factors underlie the production of methylketones in tomato trichomes. Plant Physiology, 151(4), 1952-1964.

Benning, M. M., Wesenberg, G., Liu, R., Taylor, K. L., Dunaway-Mariano, D., \& Holden, H. M. (1998). The three-dimensional structure of 4-hydroxybenzoyl-CoA thioesterase from Pseudomonas sp. strain CBS-3. Journal of Biological Chemistry, 273(50), 33572-33579.

Blum, M. S., \& Warter, S. L. (1966). Chemical releasers of social behavior. VII. The isolation of 2-heptanone from Conomyrma pyramica (Hymenoptera: Formicidae: Dolichoderinae) and its modus operandi as a releaser of alarm and digging behavior. Annals of the Entomological Society of America, 59(4), 774-779.

Dimock, M. B., \& Kennedy, G. G. (1983). The role of glandular trichomes in the resistance of Lycopersicon hirsutum f. glabratum to Heliothis zea. Entomologia Experimentalis et Applicata, 33(3), 263-268.

Forney, F., \& Markovetz, A. (1971). The biology of methyl ketones. Journal of Lipid Research, 12(4), 383-395.

Fridman, E., Wang, J., Iijima, Y., Froehlich, J. E., Gang, D. R., Ohlrogge, J., \& Pichersky, E. (2005). Metabolic, genomic, and biochemical analyses of glandular trichomes from the wild tomato species Lycopersicon hirsutum identify a key enzyme in the biosynthesis of methylketones. The Plant Cell, 17(4), 1252-1267.

Goh, E.-B., Baidoo, E. E., Keasling, J. D., \& Beller, H. R. (2012). Engineering of bacterial methyl ketone synthesis for biofuels. Applied and Environmental Microbiology, 78(1), 70-80.

Hall, R. L., \& Oser, B. L. (1965). Recent progress in consideration of flavoring ingredients under food additives amendment. 3. Gras Substances. Food Technology, 19(2P2), 151197. 
Henricsson, S., Westerholm, R., Nilsson, S., \& Berggren, B. (1996). Chemical characterisation of extractable compounds found in the coating of birch (Betula) pollen. Grana, 35(3), 179-184.

Hotelier, T., Renault, L., Cousin, X., Negre, V., Marchot, P., \& Chatonnet, A. (2004). ESTHER, the database of the $\alpha / \beta$-hydrolase fold superfamily of proteins. Nucleic Acids Research, 32, D145-D147.

Jasperson, H., \& Jones, R. (1947). Some unsaponifiable constituents of the deodorisation distillates of vegetable oils. Journal of Chemical Technology and Biotechnology, 66(1), 13-17.

Karahadian, C., Josephson, D. B., \& Lindsay, R. C. (1985). Volatile compounds from Penicillium sp. contributing musty-earthy notes to Brie and Camembert cheese flavors. Journal of Agricultural and Food Chemistry, 33(3), 339-343.

Khuat, L. U. V., Do, P. T., \& Nguyen, T. H. T. (2015). Tạo tế bào vi khuẩn Escherichia coli biểu hiện tái tổ hợp enzyme acyl thioesterase 2 (ALT2) có khả năng tổng hợp các 2methylketone chuỗi carbon ngắn và trung bình [Bacterial cell formation Escherichia coli expressing recombinant enzyme acyl thioesterase 2 (ALT2) capable of synthesizing short and medium-chain 2-methylketones]. Tạp chí Phát triển Khoa học và Công nghệ, 18(3T), 74-86.

Leadbetter, E., \& Foster, J. (1959). Oxidation products formed from gaseous alkanes by the bacterium Pseudomonas methanica. Archives of Biochemistry and Biophysics, 82(2), 491-492.

Lukins, H., \& Foster, J. (1963). Methyl ketone metabolism in hydrocarbon-utilizing mycobacteria. Journal of Bacteriology, 85(5), 1074-1087.

Moser, J. C., Brownlee, R., \& Silverstein, R. (1968). Alarm pheromones of the ant Atta texana. Journal of Insect Physiology, 14(4), 529-530.

Park, J., Rodríguez-Moyá, M., Li, M., Pichersky, E., San, K.-Y., \& Gonzalez, R. (2012). Synthesis of methyl ketones by metabolically engineered Escherichia coli. Journal of Industrial Microbiology \& Biotechnology, 39(11), 1703-1712.

Patricio, E. F. L., López, L. C., Maile, R., \& Morgan, E. D. (2003). Secretions of stingless bees: The Dufour glands of some Frieseomelitta species (Apidae, Meliponinae). Apidologie, 34(4), 359-365.

Pulsifer, I. P., Lowe, C., Narayaran, S. A., Busuttil, A. S., Vishwanath, S. J., Domergue, F., \& Rowland, O. (2014). Acyl-lipid thioesterase1-4 from Arabidopsis thaliana form a novel family of fatty acyl-acyl carrier protein thioesterases with divergent expression patterns and substrate specificities. Plant Molecular Biology, 84(4 5), 549-563.

Schaner, A. M., Tanico-Hogan, L. D., \& Jackson, L. L. (1989). (S)-2-pentadecyl acetate and 2pentadecanone Components of aggregation pheromone of Drosophila busckii. Journal of Chemical Ecology, 15(11), 2577-2588. 
Sevenants, M. R. (1983). Cream flavor composition for use with buttery flavored food products: Google patents. Retrieved October 15, 2017, from https://patents.google.com/patent/US4411924A/en

Williams, C. G. (1858). On the constitution of the essential oil of rue. Philosophical Transactions of the Royal Society of London, 148, 199-204.

Yu, G., Nguyen, T. T., Guo, Y., Schauvinhold, I., Auldridge, M. E., Bhuiyan, N., ... Noel, J. P. (2010). Enzymatic functions of wild tomato methylketone synthases 1 and 2. Plant Physiology, 154(1), 67-77. 